\title{
The Mysore Raspberry, A New Fruit for Home Gardens in the Central-Western Mountainous Region of Puerto Rico
}

\author{
Tara Singh Dhaliwal
}

\section{INTRODUCTION}

The Mysore raspberry, a new introduction, has grown and fruited fairly well in the central-western mountainous region of Puerto Rico. It is a promising new fruit for home gardens.

The Mysore raspberry, also referred to as the Ceylon raspberry or the Hill raspberry, is botanically known as Rubus albescens Roxb. (synonym, Rubus lasiocarpus Smith). It is native to the mountains of India, Ceylon, Burma, and Java, where it generally grows at an elevation of 1,500 to 10,000 feet above sea level. In India it is also cultivated to a limited extent. According to Ledin $(1,2)^{2}$ this raspberry grows and fruits well in south Florida and is recommended for cultivation in home gardens.

In this paper the performance of the Mysore raspberry in the experimental plantings at the University of Puerto Rico, Agricultural Experiment Substation at Castañer, P. R., during the past 4 years is briefly described.

\section{THE MYSORE RASPBERRY}

\section{GENERAL CHARACTERISTICS}

The canes or stems of the Mysore raspberry are glaucous and bear sharp prickles. The leaves have five to nine leaflets which possess sharp prickles along their rachis, petiole, and midrib. The upper surface of the leaflets is dark green and glabrous but the lower surface, due to the presence of numerous small white hairs, appears white. The flowers and fruits are produced in terminal and axillary clusters on young shoots. The petals and the upper part of the carpels are pink or reddish in color. The berries are roundish in shape and their diameter varies from $1 / 2$ to $3 / 4$ inch. Partly ripe berries have a red or orange-red color but the fully ripe berries have a dark purple-black color and are covered with a fine bloom (figs. 1 and 2).

${ }^{1}$ Associate Plant Breeder, Agricultural Experiment Station, University of Puerto Rico, Río Piedras, P. R. The author wishes to express his deepest appreciation to R. Bruce Ledin of the University of Florida and to William Pennock of the University of Puerto Rico for supplying the Mysore raspberry plant material for establishing the experimental plantings. The author is very grateful also to the staff of the University of Puerto Rico, Agricultural Experiment Substation at Castañer, P. R., for their assistance and cooperation during the course of this study.

2 Italic numbers in parentheses refer to Literature Cited, p. 138. 


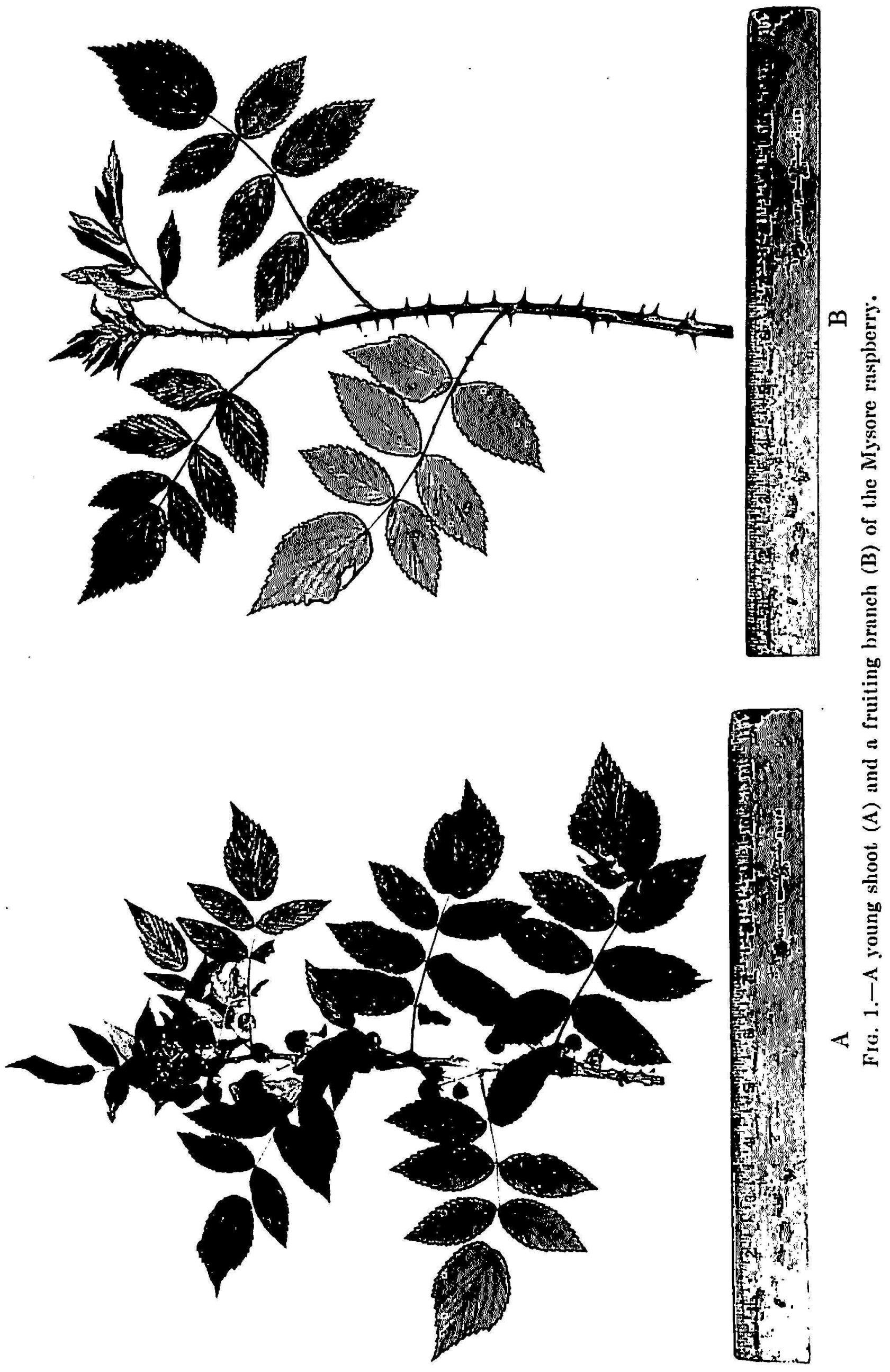


The fruits are juicy and sweet. They have good flavor and appearance. In general, the seed seem to be of the same size as those of many other raspberries commercially grown in the northern parts of the United States.

The plants produce several vigorous canes from the crown or the lower
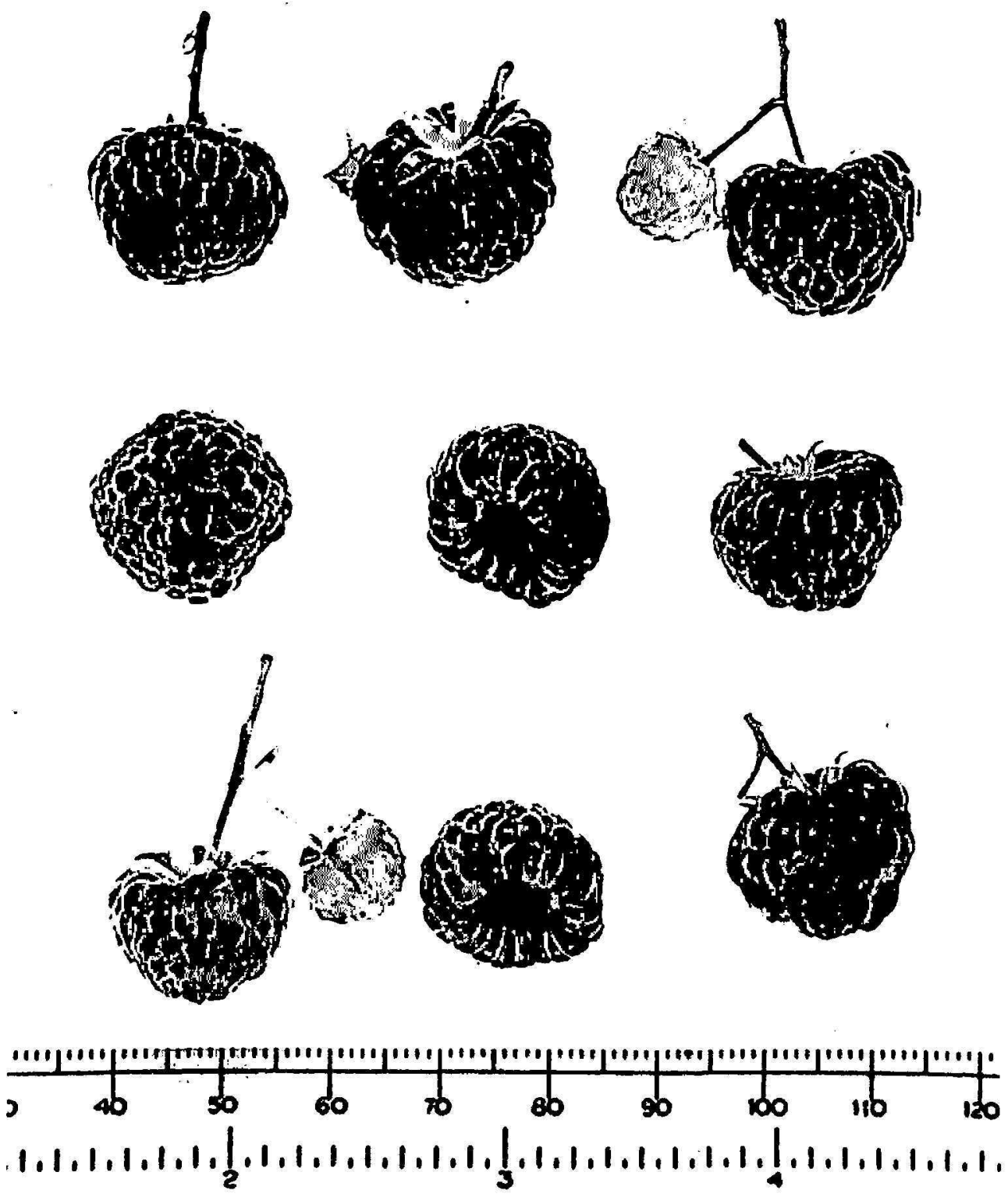

FIG. 2.-Ripe fruits of the Mysore raspberry.

part of the old stems. Unpruned canes grow to a length of 15 feet or more and may continue fruiting from December to September.

\section{PROPAGATION}

The Mysore raspberry can be propagated by seed and also by vegetative methods such as stem cuttings and tip-layers. 
The most simple and the best method of propagating the Mysore raspberry is by tip-layering. The selected cane is bent to the ground or into a 1-gallon container filled with soil. A small portion of the stem just below the terminal leaves is covered with soil to a depth of 1 to 2 inches. Within 3 to 4 weeks roots develop from the covered portion of the stem and the new plant is ready for separating from the parental plant. At Castañer tip-layering is successful at all times during the year, provided sufficient rain or irrigation water is available. The new plants should be given good care in the nursery for several months before planting them in the field.

\section{CULTURE}

At Castañer the Mysore raspberry has grown and fruited fairly well on a lateritic soil known as Alonso clay, with $\mathrm{pH}$ about 5.0. The tests by Ledin $(1,2)$ in south Florida show that this raspberry can grow even on alkaline soils. However, the plants seem to grow better on fertile soils which are well drained the year around.

The Mysore raspberry can be planted in hills or in rows. The experimental plants at Castañer are planted in hills, keeping the distance between the plants 6 to 8 feet. August and September, when it frequently rains, seem to be the best months for establishing the plants in the field at Castaner. If the plants are much taller than 18 inches they should be cut back to about that height. Generally two to three wooden posts about 6 feet high are set around each plant and one to three wires are strung between them. The canes are loosely tied to the wires and the posts.

The plants are shallow-rooted. Therefore they do not require much cultivation. However, it is necessary to weed the plantings occasionally.

During lengthy dry periods it is necessary to irrigate the plants. As the experimental plantings at Castañer are dependent on rainfall, many plants frefuently die during lengthy dry periods.

The plants require fertilizer quite frequently. In general 1 to 2 ounces of ammonium sulfate fertilizer are applied four times a year around each of the plants less than 1 year old. The older plants are usually fertilized four times a year with 9-10-5 fertilizer at the rate of 4 to 6 ounces per plant.

If not properly pruned the canes grow to a length of 15 feet or more and continue fruiting from December to September. In general, the fruits produced during the winter and spring months are of larger size and have better flavor than those produced during the summer months. In order to encourage the development of numerous young shoots which may fruit mostly during the winter and spring months it is necessary that the plants be pruned carefully.

During early summer all the dead and the old canes should be cut close to the ground and the individual plants should be thinned to four to six 
young, healthy, and vigorous canes. Towards the end of summer these canes should be cut back to a height of 5 to 6 feet to encourage the development of lateral branches. After a few months these lateral branches should be cut back to a length of 8 to 10 inches to force the development of secondary lateral branches on which the fruits are borne.

\section{SPREAD AS A WILD PLANT}

The Mysorc raspberry produces numerous seed which can be carried to far-off places by human beings, birds, streams, etc. Upon germination these seed can produce wild plants.

To determine whether this raspberry has so far established itself in the wild, the surroundings of its experimental plantings at Castañer have been carefully searched. A few very weak wild seedlings of this raspberry were found growing quite close to the experimental plantings.

Probably under natural conditions only a small percentage of the seed of this raspberly germinate and, because of attack by damping-off fungi, or strong sunshine or long dry periods, etc., only a few of them survive and grow large enough to be noticed easily. The wild raspberry plants remain very weak as they are not given the cultural treatments needed for their proper growing and fruiting under the prevailing environmental conditions. Thus it is quite unlikely that this raspherry can spread as a wild plant in this region of Puerto Rico.

Ledin (2), after several years of study of the Mysore raspberry, concluded that it was quite unlikely that this raspberry would establish as a wild plant in south Florida.

\section{DISLASES AND INSECT PESTS}

The Mysore raspberry plants do not seem to suffer from serious diseases and insect pests at present. However, occasionally birds eat the ripe berries, but as they are not numerous in Puerto Rico they do not seem to present a serious problem for raspberry cultivation.

\section{PICKing:}

When the Mysore raspberry plants are bearing heavily it is advisable to pick the berries at least twice a week. Only fully ripe berries, which are usually dark purple-black and easily separate from the core without crumbling, should be picked. If the ripe berries are not picked in time their color fades to deep red and mold develops on them. Many of them also fall to the ground, especially if the planting is exposed to strong winds and the canes are not tied securely to the posts or the wires. The berries should not be picked when they are wet. Care should be taken not to injure them in any way. As for other raspberrics several types of containers can be used 
to pick the Mysore raspberry, but the wooden pint-size berry boxes seem to be quite satisfactory.

\section{YIELD}

Because of many disturbing factors it has not been possible to collect sufficient yield data from the experimental Mysore raspberry plants growing at Castañer. It is observed that the plants which are under light natural shade for a part of the day bear a relatively heavy crop, whereas those which are exposed to strong sunshine all day bear a relatively light crop. It seems that with good care an individual bush which has been in the field for 1 to 2 years can produce several pounds of ripe berries during a year.

\section{USE OF FRUITS}

For the past 4 years the berries picked from the experimental Mysore raspberry plantings at Castañer have been supplied to a large number of persons and the information has been collected concerning their consumption. The berries are good for eating fresh. They can also be mixed with sugar and cream and served as a dessert, or be used for making jellies, jams, pies, etc.

\section{COMMERCIAL PRODUCTION POSSIBILITIES}

It is quite possible that in future some better raspberry varieties may be introduced into Puerto Rico or developed here through careful selection and hybridization. However, at present, the Mysore seems to be the only desirable raspberry which grows and fruits fairly well in the centralwestern mountainuous region of Puerto Rico. As it is a new fruit it should be planted on a small scale for consuming the fruits at home and for exploring the possibility of their sale in suitable markets.

\section{SUMMARY}

The Mysore raspberry, Rubus albescens Roxb. (synonym, Rubus lasiocarpus Smith) has recently been introduced into Puerto Rico. The experimental plantings of this raspberry have been established at the University of Puerto Rico, Agricultural Experiment Substation, at Castañer, situated in the middle of the central-western mountainous region of the Island.

Based on the study of the experimental plantings for the past 4 years the general characteristics, propagation, culture, use of fruits, etc., of the Mysore raspberry have been briefly presented in this paper.

The Mysore raspberry has grown fairly well at Castañer. If the cultural practices are employed carefully it produces well-flavored, sweet, and juicy berries over a period of several months during the year. The fruits are good for eating fresh and also for making jellies, jams, etc. It is a promising new 
fruit for small-scale production in the central-western mountainous region of Puerto Rico.

\section{RESUMEN}

En este artículo se informa sobre los estudios experimentales realizados con la frambuesa de Mysore Rubus albescans Roxb. (sinonimia, Rubus lasiocarpus Smith) recientemente introducida por la Estación Experimental Agrícola de la Universidad de Puerto Rico y sembrada en la Subestación en Castañer, la cual está ubicada en la región montañosa del oestecentral de la Isla.

El estudio comprende ensayos de investigación que tuvieron que ver con los caracteres generales de la planta, su propagación, cultivo y uso de la fruta y que se llevaron a cabo por 4 años.

La frambuesa de Mysore crece bastante bien en Castañer. Con prácticas de cultivo adecuadas, la planta produce frutas de buen sabor, dulces y jugosas durante varios meses del año. Las frutas pueden consumirse frescas, en jaleas, en cristal, etc. Tal parece que ésta es una nueva fruta con posibilidades de arraigo en la región montañosa de Puerto Rico para siembras en pequeña escala.

\section{LITERATURE CITED}

1. Ledin, R. B., A Tropical Black Raspberry for South Florida, Univ. of Fla. Agr. Exp. Sta., Gainesville, Fla., Cir. S-56, February 1953.

2.-, Mysore black raspberry, new fruit for home gardens, Fla. Grower, pp. 5 and 24, July 1953. 